\title{
The Effect of Residual Insulin Secretion on Exocrine Pancreatic Function in Juvenile-onset Diabetes Mellitus
}

\author{
B. M. Frier, O. K. Faber, C. Binder, and H. L. Elliott \\ Division of Medicine, Ninewells Hospital and Medical School, Dundee, Scotland, and Hvidøre Hospital, Klampenborg, Denmark
}

Summary. Residual beta cell function was studied in 18 juvenile-onset diabetics by measuring serum $\mathrm{C}$ peptide immunoreactivity (CPR) fasting, and after IV injection of glucagon ( $1 \mathrm{mg})$. This was compared with the exocrine pancreatic response to an IV infusion of secretin and cholecystokinin-pancreozymin. Outputs of pancreatic bicarbonate, amylase and trypsin were measured. Exocrine secretory pancreatic function was decreased in 14 patients. Fasting and maximal CPR showed that 9 patients had residual insulin secretion. For these 'CPR-secretors' there was a strong correlation between CPR and output of bicarbonate $(r=0.87, p<0.005)$ and amylase $(r=$ $0.7, \mathrm{p}<0.05$ ), but not with trypsin. These results suggest the existence of an endocrine-exocrine relationship in the pancreas.

Key words: C-peptide, exocrine pancreas, amylase, bicarbonate, beta-cell function, diabetes mellitus.

Exocrine pancreatic function has been reported as abnormal in juvenile-onset diabetes mellitus [1-5], and has been shown to deteriorate progressively with increasing duration of the disease [5]. This decline in exocrine pancreatic function occurs in the 5 to 10 years after the onset of insulin-dependent diabetes. Quantitative measurements of serum C-peptide immunoreactivity (CPR) have shown that most juvenile-type diabetic patients have some residual capacity to produce insulin for up to 6 years after developing diabetes $[6,7]$. Thereafter, the prevalence of residual beta cell function decreases, to reach a plateau of about 15 per cent of normal between 15 and 35 years after the onset of the disease [8].
The exocrine and endocrine pancreatic functions of a group of patients with juvenile-onset diabetes, have been evaluated to study a possible relationship between endogenous insulin secretion and exocrine pancreatic function in diabetes.

\section{Patients and Methods}

The exocrine pancreatic secretory capacity of 18 patients with juvenile-onset diabetes of varying duration was studied by measuring the outputs of bicarbo-

Table 1. Clinical details of 18 juvenile-onset diabetic patients

\begin{tabular}{|c|c|c|c|c|c|c|c|}
\hline 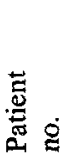 & 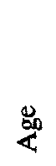 & బ & 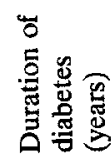 & 它. & 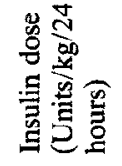 & 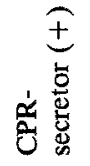 & 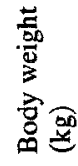 \\
\hline 1 & 26 & $\mathbf{F}$ & 0.5 & Lente & 0.44 & + & 63.7 \\
\hline 2 & 22 & M & 0.5 & Lente & 0.47 & + & 68.5 \\
\hline 3 & 14 & $\mathbf{F}$ & 1 & NPH, Sol. & 0.91 & + & 52.5 \\
\hline 4 & 17 & $\mathbf{M}$ & 3 & NPH, Sol. & 0.79 & + & 70.4 \\
\hline 5 & 20 & $\mathbf{F}$ & 3 & Sol. & 1.39 & + & 46.0 \\
\hline 6 & 17 & $\mathbf{M}$ & 5 & Actr., Mono & 2.02 & + & 55.4 \\
\hline 7 & 20 & $\mathbf{F}$ & 7 & NPH, Sol. & 0.73 & + & 59.9 \\
\hline 8 & 46 & $\mathbf{M}$ & 10 & NPH. & 0.70 & + & 85.6 \\
\hline 9 & 29 & $\mathbf{M}$ & 15 & NPH, Sol. & 1.19 & + & 63.8 \\
\hline 10 & 25 & M & 3 & NPH, Sol. & 1.13 & - & 71.0 \\
\hline 11 & 16 & $\mathbf{F}$ & 3 & NPH, Sol. & 1.38 & - & 65.0 \\
\hline 12 & 29 & $\mathbf{M}$ & 4 & Lente, Nuso & 0.58 & - & 76.5 \\
\hline 13 & 34 & M & 9 & NPH, Sol. & 0.84 & - & 81.4 \\
\hline 14 & 33 & $\mathbf{F}$ & 11 & NPH, Sol. & 0.88 & - & 72.4 \\
\hline 15 & 39 & M & 13 & NPH, Sol. & 1.11 & - & 86.8 \\
\hline 16 & 30 & $\mathbf{F}$ & 14 & Lente & 0.30 & - & 53.4 \\
\hline 17 & 34 & $\mathbf{M}$ & 17 & NPH, Sol. & 0.87 & - & 64.4 \\
\hline 18 & 56 & $\mathbf{F}$ & 21 & NPH, Sol. & 1.09 & - & 47.5 \\
\hline
\end{tabular}


Table 2. Exocrine pancreatic function and C-peptide immunoreactivity (CPR) of diabetic patients

\begin{tabular}{|c|c|c|c|c|c|}
\hline \multirow[b]{3}{*}{$\begin{array}{l}\text { Patient no. } \\
\text { 'CPR-secretors' }\end{array}$} & \multicolumn{5}{|c|}{ Pancreatic stimulation (Secretin/CCK-PZ) } \\
\hline & \multirow{2}{*}{$\begin{array}{l}\text { Bicarbonate } \\
\text { output }(\mathrm{mmol} / \mathrm{h}) \\
\text { lower limit of } \\
\text { normal } 20\end{array}$} & \multirow{2}{*}{$\begin{array}{l}\text { Amylase } \\
\text { out-put }(\mathrm{mol} / \mathrm{h}) \\
\text { low-er limit of } \\
\text { nor-mal } 8\end{array}$} & \multirow{2}{*}{$\begin{array}{l}\text { Trypsin } \\
\text { output }(\mu \mathrm{g} / \mathrm{h}) \\
\text { lower limit of } \\
\text { normal } 160\end{array}$} & \multicolumn{2}{|c|}{$\begin{array}{l}\text { C-peptide } \\
\text { immunoreactivity }\end{array}$} \\
\hline & & & & \multicolumn{2}{|c|}{$\mathrm{pmol} / \mathrm{ml}$} \\
\hline 1 & 24.2 & 4.9 & 57 & 0.15 & 0.16 \\
\hline 2 & 30.4 & 24.2 & 165 & 0.20 & 0.21 \\
\hline 3 & 24.4 & 17.2 & 218 & 0.15 & 0.16 \\
\hline 4 & 27.0 & 25.6 & 228 & 0.24 & 0.26 \\
\hline 5 & 13.3 & 2.7 & 122 & 0.07 & 0.09 \\
\hline 6 & 17.4 & 7.0 & 85 & 0.10 & 0.13 \\
\hline 7 & 19.2 & 17.6 & 57 & 0.06 & 0.08 \\
\hline 8 & 17.8 & 5.4 & 109 & 0.07 & 0.08 \\
\hline 9 & 13.2 & 9.8 & 152 & $\underline{0.06}$ & 0.07 \\
\hline Mean $\pm S D$ & $20.8 \pm 6.0$ & $12.7 \pm 8.6$ & $133 \pm 63$ & $0.12 \pm 0.06$ & $0.14 \pm 0.06$ \\
\hline \multicolumn{6}{|c|}{ 'CPR-non-secretors' } \\
\hline 10 & 21.6 & 8.3 & 178 & \multicolumn{2}{|l|}{ CPR } \\
\hline 11 & 13.3 & 8.0 & 86 & & \\
\hline 12 & 21.0 & 16.1 & 153 & \multicolumn{2}{|l|}{ not } \\
\hline 13 & 23.4 & 7.5 & 75 & \multirow{6}{*}{\multicolumn{2}{|c|}{ detectable }} \\
\hline 14 & 9.6 & 4.2 & 120 & & \\
\hline 15 & 17.2 & 6.2 & 122 & & \\
\hline 16 & 14.9 & - & 85 & & \\
\hline 17 & 16.2 & 9.0 & 129 & & \\
\hline 18 & 7.2 & 9.2 & 98 & & \\
\hline Mean $\pm S D$ & $16.0 \pm 5.5$ & $8.6 \pm 3.5$ & $116 \pm 34$ & & \\
\hline
\end{tabular}

nate, amylase and trypsin, in response to secretin (1 clinical unit/kg-h) and cholecystokinin-pancreozymin (CCK-PZ) (1 Ivy unit $/ \mathrm{kg}$-h). Clinical details of the patients studied are shown in Table 1 . All subjects were within ten per cent of their ideal body weight, and were studied after an overnight fast. Duodenal aspirate was collected by continuous mechanical suction through a multiple-lumen tube, the distal end of which was positioned in the second part of the duodenum, with the proximal aspiration site in the gastric antrum. After a $15 \mathrm{~min}$ basal collection, secretin and CCK-PZ in $0.15 \mathrm{mmol} / 1$ sodium chloride were infused intravenously for 45 minutes. Bicarbonate, amylase and trypsin concentrations were measured in the collected duodenal aspirate by the methods described in a previous report [5]. The results were expressed as output per hour by doubling the sum of the outputs during the steady state response of the final two 15 minute periods of hormonal stimulation.

The capacity to secrete insulin in the same group of patients was assessed within three to nine months of the studies of exocrine pancreatic function. Informed consent was obtained for both studies. The patients were again studied after an overnight fast and 24 hours after the last injection of insulin. No subjects had clinical or urinary evidence of ketosis. Venous blood samples were obtained 10,5 and $0 \mathrm{~min}$ before an intravenous bolus injection of $1 \mathrm{mg}$ glucagon (Eli Lilly) and thereafter at 2, 4, 6, 8, 10, 15 and 20 minutes [9]. Serum CPR was assayed as described by Heding [10], using the antibody M1230 [11], with an effective detection limit of $0.06 \mathrm{pmol} / \mathrm{ml}$. (Normal fasting CPR values range from 0.26 to $0.63 \mathrm{pmol} / \mathrm{ml}$ and rise after stimulation with glucagon to a range of 0.41 to $1.88 \mathrm{pmol} / \mathrm{ml}$ [9].) Statistical significance (p) was estimated using Student's $t$ test and by determination of the correlation coefficient (r) [12].

\section{Results}

The exocrine secretory pancreatic function was reduced in 14 patients, and was better preserved in the patients who had diabetes for less than 5 years.

The fasting CPR and maximum CPR after stimulation are shown in Table 2, with the bicarbonate, amylase and trypsin outputs for each patient, as previously reported [5]. Nine of the patients were found to have residual insulin secretion as shown by a fasting CPR of $0.06 \mathrm{pmol} / \mathrm{ml}$ or above (Table 2). These nine patients were designated 'CPR-secretors' and 
their CPR was compared with each measured parameter of exocrine pancreatic function. Good correlation was observed between the maximum $\mathrm{CPR}$ and bicarbonate output $(\mathrm{r}=0.87, \mathrm{p}<0.005)$. A significant correlation was also found with the amylase output $(\mathrm{r}=0.7, \mathrm{p}<0.05)$, but not with trypsin output. A similar correlation was observed with fasting CPR.

Mean values of bicarbonate, amylase and trypsin outputs were compared in 'CPR-secretors' and 'CPR-non-secretors' with diabetes for less than 5 years. Mean bicarbonate output was 23.9 ( $\mathrm{SD} \pm$ 6.4) $\mathrm{mmol} / \mathrm{h}$ in the 'CPR-secretors' compared to 18.6 (SD \pm 4.6$) \mathrm{mmol} / \mathrm{h}$ in the 'non-secretor' group; mean amylase output was $14.9(\mathrm{SD} \pm 10.7) \mathrm{mol} / \mathrm{h}$ compared to $10.8(\mathrm{SD} \pm 4.6) \mathrm{mol} / \mathrm{h}$, and mean trypsin output was $158(\mathrm{SD} \pm 71) \mu \mathrm{g} / \mathrm{h}$ compared to 139 $(\mathrm{SD} \pm 48) \mu \mathrm{g} / \mathrm{h}$. Although the values tended to be higher in the 'CPR-secretor' group, this was not statistically significant. In subjects with diabetes for more than 5 years, there was no difference in exocrine pancreatic function between the 'CPR-secretors' and 'CPR-non-secretors'.

\section{Discussion}

This study has demonstrated a significant correlation between exocrine pancreatic function and residual insulin-secreting capacity in nine patients with juvenile-onset diabetes who retained some beta cell function.

The residual beta cell function was assessed by determination of CPR before and after stimulation with glucagon, but the observed rise was less than expected [9]. In insulin treated patients with residual beta cell function, human proinsulin may accumulate in plasma by binding to endogenous insulin antibodies [13] and cross reaction of proinsulin in the Cpeptide assay causes an overestimation of C-peptide and a diminished response to stimulation with glucagon. In our patients, the total concentration of human proinsulin was 1.7 to 7.5 times higher than the measured $\mathrm{C}$-peptide concentrations on a molar basis. Proinsulin cross reacts no more than 11 per cent on a molar basis with C-peptide [14], and some of the proinsulin is removed by the preincubation of serum with excess of insulin-antibodies covalently bound to sepharose [10]. A significant contribution of proinsulin to the measured CPR is therefore considered to be low except in subject 2 , whose total proinsulin concentration was $4.2 \mathrm{pmol} / \mathrm{ml}$.

A few of the patients with no residual beta cell function (nos 10,12) have moderately well-preserved exocrine pancreatic function compared to the 'CPR-secretor' group, despite their endogenous insulin deficiency. These patients have had diabetes for less than 5 years and have not had time to develop the severe loss of functional capacity observed with increasing duration of the disease [5]. This would suggest, however, that factors other than failure to secrete insulin are involved in the production of exocrine pancreatic deficiency in juvenile-onset diabetes. Antibodies to exocrine pancreatic tissue have been described in diabetes [15] and it is possible that our findings may represent a parellel and unrelated deterioration in exocrine and endocrine pancreatic function, occurring over a period of years after the development of diabetes.

There is evidence in animals, however, that insulin is necessary to regulate the synthesis of pancreatic amylase, and may exert a trophic effect of peri-insular acini by promoting amino acid uptake [16-20]. The significant correlation between pancreatic amylase-secretory capacity and endogenous insulin production in diabetic patients suggests that insulin deficiency in man has a definite adverse effect on amylase secretion. A similar correlation has been suggested in patients with chronic pancreatitis [21].

The correlation between CPR and bicarbonate output is surprising, as insulin is not thought to influence bicarbonate secretion. It is possible that the deficiency in bicarbonate-secreting capacity in juvenile-onset diabetics is caused by structural damage to the duct cells by fibrosis and infiltration of fat [22]. It is not clear if this is the direct result of insulin lack on acinar and duct tissues, but vacuolation of intralobular ducts has been described in the pancreas of dogs with experimental diabetes, while other acinar tissue remains histologically normal [23-25].

Trypsin output has been shown to be diminished in juvenile-onset diabetes $[4,5]$, but insulin does not enhance the secretion of a similar protease enzyme, chymotrypsinogen, in alloxan diabetic rats $[16,18]$. Our finding of a poor correlation of trypsin output with CPR is therefore not unexpected.

Our findings support the hypothesis of Henderson [26] that high local concentrations of islet hormones play a significant role in the function of the exocrine pancreas. The disruption of an endocrineexocrine interaction in the diabetic pancreas could therefore be a major causal factor in the progressive deterioration of exocrine pancreatic function in juvenile-onset diabetes. The partial preservation of endogenous insulin secretion in maturity-onset diabetes would explain why exocrine pancreatic function is less abnormal in these patients $[5,27,28]$. This study does not elucidate the mechanism by which insulin may influence exocrine pancreatic secretion, but does suggest the existence of an endocrine-exocrine relationship in the pancreas, which is progressively disrupted in juvenile-onset diabetes. 
Acknowledgements. We thank Dr. L.G. Heding for proinsulin measurements, Miss J. Falck for technical assistance, Mrs P. Hollis for secretarial help and Professor I. A. D. Bouchier for encouragement and advice.

\section{References}

1. Chey, W. Y., Shay, H., Shuman, C.R.: External pancreatic secretion in diabetes mellitus. Ann. Intern. Med. 59, 812-821 (1963)

2. Vacca, J. B., Henke, W.J., Knight, W. A., Jr.: The exocrine pancreas in diabetes mellitus. Ann. Intern. Med. 61, 242-247 (1964)

3. Bock, O.A. A., Bank, S., Marks, I. N., Jackson, W.P.U.: Exocrine pancreatic function in diabetes mellitus. S. Afr. Med. J. 41, 756-758 (1967)

4. Domschke, W., Tympner, F., Domschke, S., Demling, L.: Exocrine pancreatic function in juvenile diabetics. Am. J. Dig. Dis. 20, 309-312 (1975)

5. Frier, B.M., Saunders, J.H. B., Wormsley, K. G., Bouchier, I. A.D.: Exocrine pancreatic function in juvenile-onset diabetes mellitus. Gut 17, 685-691 (1976)

6. Faber, O.K., Binder, C., Hendriksen, C., Drejer, J., Heding, L.G.: Plasma C-peptide response to glucagon as a measure of $\beta$-cell function in insulin dependent diabetes mellitus. Diabetes 25 (Suppl. 1), 329 (1976)

7. Grajwer, L.A., Pildes, R.S., Horwitz, D. L., Rubenstein, A. H.: Control of juvenile diabetes mellitus and its relationship to endogenous insulin secretion as measured by C-peptide immunoreactivity. J. Pediatr. 90, 42-48 (1977)

8. Madsbad, S., Faber, O. K., Binder, C., McNair, P., Christiansen, C., Transbøl, I.: Prevalence of residual beta-cell function in insulin-dependent diabetics in relation to age at onset and duration of diabetes. Diabetes (1978) (in press)

9. Faber, O.K., Binder, C.: C-peptide response to glucagon: A test for the residual $\beta$-cell function in diabetes mellitus. Diabetes 26, 605-610 (1977)

10. Heding, L. G.: Radioimmunological determination of human C-peptide in serum. Diabetologia 11, 541-548 (1975)

11. Faber, O. K., Markussen, J., Naithani, V.K., Binder, C.: Production of antisera to synthetic benzyloxycarbonyl-C-peptide of human pro-insulin. Hoppe Seylers Z. Physiol. Chem. 357, 751-757 (1976)

12. Diem, K., Lentner, C.: Correlation coefficient. In: Documenta Geigy, Scientific Tables, pp. 179-180. Basle, Switzerland: J. R. Geigy 1970

13. Fink, G., Cresto, J.C., Gutman, R. A., Lavine, R. L., Rubenstein, A. H., Recant, L.: Plasma proinsulin-like material in insulin treated diabetics. Horm. Metab. Res. 6, 439-443 (1974)

14. Faber, O. K., Binder, C., Markussen, J., Heding, L. G., Nai- thani, V.K., Kuzuya, H., Blix, P., Horwitz, D., Rubenstein, A. H.: Characterization of seven C-peptide antisera. Diabetes (1978) (in press)

15. Bloom, S. R., West, A. M., Polak, J. M., Barnes, A. J., Adrian, T.E.: Hormonal contaminants of insulin. In: S. R. Bloom. (Ed.): Gut Hormones Chapter 51. Edinburgh: Churchill Livingstone (in press)

16. Ben Abdeljlil, A., Palla, T.C., Desnuelle, P.: Effect of insulin on pancreatic amylase and chymotrypsinogen. Biochem. Biophys. Res. Commun. 18, 71-75 (1965)

17. Söling, H.D., Unger, K. O.: The role of insulin in the regulation of $\alpha$-amylase synthesis in the rat pancreas. Eur. J. Clin. Invest. 2, 199-212 (1972)

18. Adler, G., Kern, H. F.: Regulation of exocrine pancreatic secretory process by insulin in vivo. Horm. Metab. Res. 7, 290-296 (1975)

19. Hansson, G.: The formation of pancreatic juice proteins studied with labelled amino acids. Acta Physiol. Scand. 46 [Suppl. 161], 1-99 (1959)

20. Palla, T. C., Abdeljlil, A. Ben, Desnuelle, P.: Effect of insulin on the rate of biosynthesis of some pancreatic enzymes (Abstract). Gut 9, 254 (1968)

21. Ohlsen, P.: Endocrine and exocrine function in pancreatitis. Acta Med. Scand. [Suppl.] 484, 1-99 (1968)

22. Warren, S., LeCompte, P.M., Legg, M. A.: In: The Pathology of Diabetes Mellitus, pp. 102-115 and 351-363. London: Kimpton 1966

23. Goldner, M. G., Gomori, G.: Alloxan diabetes in the dog. Endocrinology 33, 297-308 (1943)

24. Grossman, M. I., Ivy, A.C.: Effect of alloxan upon external secretion of the pancreas. Proc. Soc. Exp. Biol. Med. 63, 62-63 (1946)

25. Richardson, K.C., Young, F. G.: Histology of diabetes induced in dogs by injection of anterior pituitary extracts. Lancet 1938 I, 1098-1101

26. Henderson, J.R.: Why are the islets of Langerhans? Lancet 1969 II, $469-470$

27. Baron, J. H., Nabarro, J. D. N.: Pancreatic exocrine function in maturity onset diabetes mellitus. Br. Med. J. 1973 IV, 25-27

28. Peters, N., Dick, A.P., Hales, C. N., Orrell, D. H., Sarner, M.: Exocrine and endocrine function in diabetes mellitus and chronic pancreatitis. Gut 7, 277-280 (1966)

Received: November 28, 1977,

and in revised form: January 13, 1978

Dr. B. M. Frier

Department of Medicine

Western General Hospital

Edinburgh, EH4 2XU

Scotland 